\title{
Immunoterapia na jad owadów błonkoskrzydłych - kiedy i kogo kwalifikować do leczenia
}

\section{Hymenoptera venom immunotherapy - when and whom to qualify for treatment}

Weronika Sułkowska1, Ewa Czarnobilska',2

${ }^{1}$ Centrum Alergologii Klinicznej i Środowiskowej, Szpital Uniwersytecki w Krakowie 2 Zakład Alergologii Klinicznej i Środowiskowej, Katedra Toksykologii i Chorób Środowiskowych, Wydział Lekarski, Uniwersytet Jagielloński - Collegium Medicum

\begin{abstract}
Streszczenie:
Alergia na jad owadów błonkoskrzydłych to najczęstsza przyczyna wstrząsu anafilaktycznego u dorosłych, a druga po alergii pokarmowej u dzieci. W warunkach polskich najczęstszymi przyczynami alergii są użądlenia przez pszczoły miodne (Apis mellifera), osy (Vespula spp.) oraz szerszenie (Vespa spp., częściej u osób już wcześniej żądlonych przez osy).

Skutkiem użądlenia jest zazwyczaj odczyn miejscowy, jednak ok. 3\% dorosłych i 0,5\% dzieci reaguje odczynami ogólnoustrojowymi o charakterze anafilaksji. Diagnostyka nadwrażliwości na jady bywa trudna, szczególnie gdy wywiad nie wskazuje jednoznacznie na owada sprawczego. Jej podstawą są testy skórne z jadem osy i pszczoły: punktowe (prick test) i śródskórne o tącznej czułości 94\%, i oznaczenie poziomu specyficznych lgE, których czułość wynosi od 83\% do 100\%. Postawą leczenia jest immunoterapia swoista, do której są kwalifikowani pacjenci z ciężkimi reakcjami anafilaktycznymi i udowodnionym mechanizmem IgE-zależnym alergii. W wyjątkowych sytuacjach do leczenia są kwalifikowane osoby z dużymi odczynami miejscowymi narażone na częste użądlenia z racji wykonywanej pracy oraz z izolowanymi zmianami skórnymi, które znacznie obniżają jakość ich życia. Immunoterapia swoista jest jedyną skuteczną metodą leczenia, trwa 3-5 lat, a jej skuteczność wynosi 91-96\% przy alergii na jad osy oraz $77-84 \%$ przy alergii na jad pszczoły.
\end{abstract}

\begin{abstract}
:
Hymenoptera venom allergy is the most common cause of anaphylactic shock in adults. In children it is second cause, just after food allergy. In Poland, the most common causes of allergies are stings by honeybees (Apis mellifera), wasps (Vespula spp.) and hornets (Vespa spp.). Usually sting cause a local reaction, however, in approximately $3 \%$ of adults and $0.5 \%$ of children the reaction is systemic anaphylaxis. The diagnosis of venom hypersensitivity can be difficult, especially when the medical interview does not clearly indicate the causative insect. The diagnosis bases on skin tests with wasp and bee venom: prick test and intradermal (with a total sensitivity of $94 \%$ ), and determination of the level of specific lgE (the sensitivity of the test ranges from $83 \%$ to $100 \%$ ). The mainstay of treatment is specific immunotherapy, for which patients with severe anaphylactic reactions and a proven IgE-dependent mechanism of allergy are qualified. In exceptional situations, patients with severe local reactions, exposed to frequent stings due to their work and with isolated skin lesions, which significantly reduce their quality of life are qualified for the treatment. Specific immunotherapy is the only effective treatment method, it lasts $3-5$ years, and its effectiveness is $91-96 \%$ in wasp venom allergy and $77-84 \%$ in bee venom allergy.
\end{abstract}

Słowa kluczowe: alergia na jad, immunoterapia swoista, VIT, uczulenia na jad owadów

Key words: venom allergy, specific immunotherapy, VIT, allergy to insect venom 
Rycina 1. Algorytm postępowania po użądleniu przez owada błonkoskrzydtego.

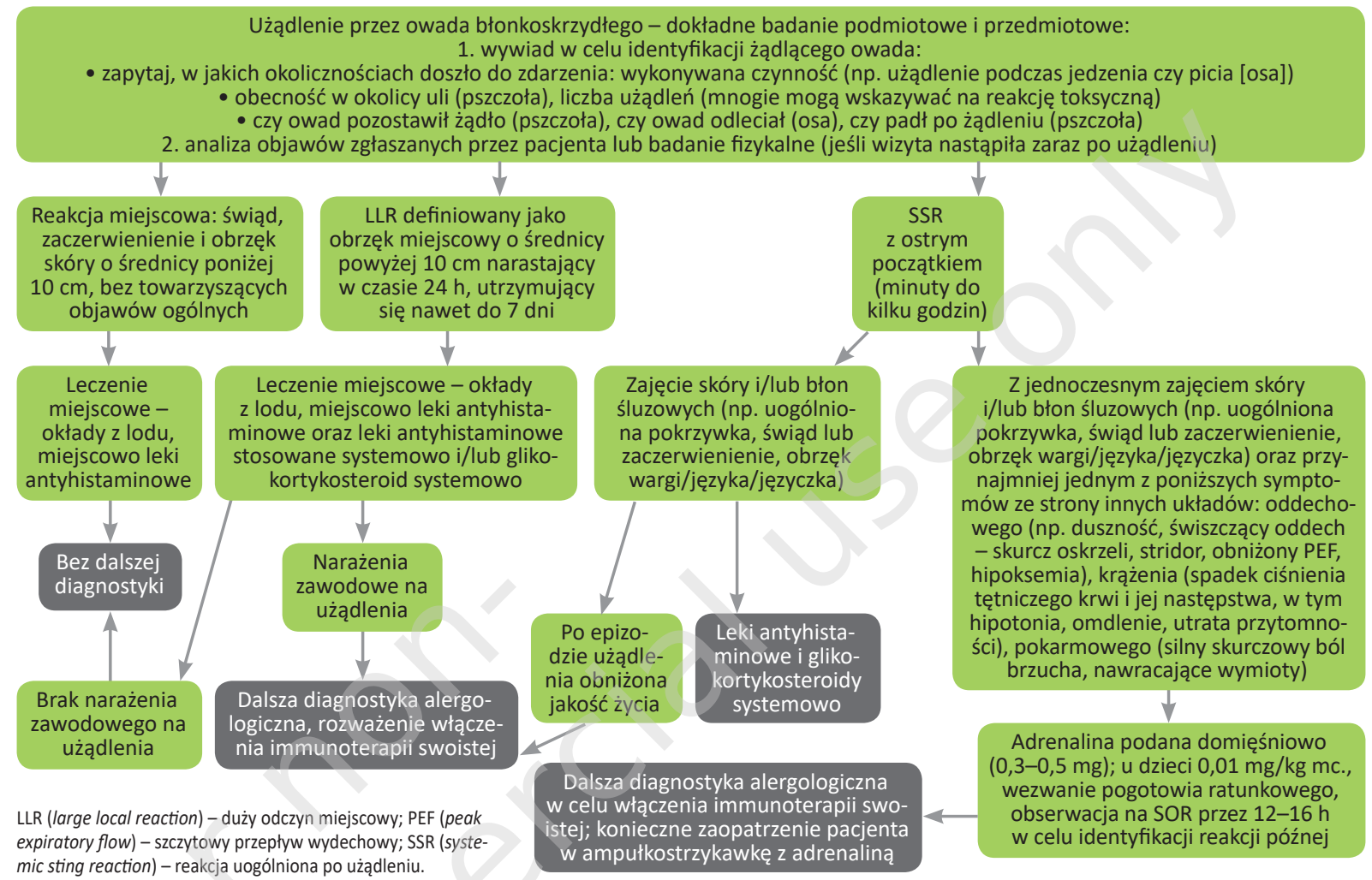

\section{Wstęp}

Przyczyną alergii w naszej szerokości geograficznej najczęściej są użądlenia przez pszczoły miodne (Apis mellifera), osy (Vespula spp.) oraz szerszenie (Vespa spp., częściej u osób już wcześniej żądlonych przez osy). Ostatnimi czasy mówi się wiele również o alergii na jad trzmieli, jako że są one używane jako zapylacze na plantacjach szklarniowych. Temat alergii zarówno na jady owadów, jak i na leki oraz alergeny pokarmowe i wziewne przybrał na sile na przełomie lat 2020 i 2021, kiedy rozpoczęły się szczepienia populacyjne przeciwko COVID-19, a w ankiecie kwalifikacji pojawiły się pytania o poszczególne alergie. 28 grudnia 2020 r. ukazały się rekomendacje zespołu ekspertów pod kierunkiem konsultanta krajowego w dziedzinie alergologii dotyczące szczepienia przeciwko COVID-19, w którym zalecono zachowanie szczególnej ostrożności przy podejmowaniu decyzji o szczepieniu u pacjentów z wywiadem anafilaksji lub ciężkiej reakcji alergicznej, spowodowanej takimi czynnikami, jak: leki, szczepionki, lateks, pokarmy, jady owadów, czynniki fizykalne i inne [1].

Następnie pojawiły się rekomendacje Polskiego Towarzystwa Alergologicznego dotyczące kwalifikacji osób z alergią i anafilaksją do szczepienia przeciw COVID-19, w których jasno stwierdzono na podstawie najnowszych doniesień naukowych i doświadczeń, że występowanie epizodów IgE-zależnej anafilaksji na pokarmy, jady owadów, alergeny powietrznopochodne nie zwiększa ryzyka rozwoju reakcji anafilaktycznej po szczepieniu przeciw COVID-19. Jednak ryzyko wystąpienia reakcji nadwrażliwości po podaniu szczepionki przeciw COVID-19 jest podwyższone u każdego chorego z wywiadem wskazującym na przebycie reakcji anafilaktycznej, zwłaszcza wielokrotnej lub o nieznanej przyczynie. Dlatego takim pacjentom należy zalecać zindywidualizowane środki ostrożności, takie jak szczepienie w przyszpitalnych punktach szczepień z możliwością natychmiastowego i specjalistycznego leczenia anafilaksji, profilaktyczne zaopatrzenie w dostęp dożylny przed podaniem szczepionki czy też wydłużenie czasu obserwacji po jej podaniu do 30 min. Jedynym bezwzględnym przeciwwskazaniem do podania dostępnych obecnie szczepionek przeciwko COVID-19 jest reakcja nadwrażliwości na składniki szczepionki wymienione w charakterystyce produktu leczniczego [2].

\section{Epidemiologia}

Szacuje się, że ok. 56-95\% populacji w trakcie swojego życia zostało użądlone przez owada błonkoskrzydłego [3]. Wśród nich ok. 3\% dorosłych i 0,5\% dzieci doświadczyło reakcji uogólnionej, jednak w większości przypadków jest to odczyn miejscowy o różnym nasileniu [4]. 
Grupą szczególnie narażoną na użądlenia przez pszczoły są pszczelarze oraz ich rodziny. W tej populacji częstość reakcji uogólnionych jest większa niż w populacji ogólnej i szacuje się ją od 30\% do nawet 45\% [4]. Wiele czynników wpływa na ciężkość ich przebiegu. Są to m.in.: liczba i częstotliwość użądleń, staż pracy w pasiece, pora roku, w której doszło do użądlenia, rozpoznana wcześniej astma oskrzelowa czy inna alergia. I tak - pszczelarze z dłuższym stażem pracy, częściej i intensywniej żądleni, rzadziej prezentują symptomy ciężkiej systemowej reakcji $[5,6]$. Jednakże ok. $60 \%$ tej populacji prezentuje bezobjawowe uczulenie potwierdzone podwyższonym poziomem specyficznych IgE (sIgE) przeciw jadowi pszczoły oraz dodatnimi testami skórnymi [4]. Innymi grupami zawodowymi narażonymi na częstsze żądlenia owadów są także: ogrodnicy, rolnicy, leśnicy, osoby zawodowo uprawiające sport na wolnym powietrzu, jak również cukiernicy, piekarze, sprzedawcy warzyw i owoców.

Zarówno doświadczenie reakcji systemowej, jak i rozległego odczynu skórnego po użądleniu często powoduje u pacjentów traumę, niepokój o własne życie i w efekcie obniża jego jakość. W sezonie wiosenno-letnim unikają oni przebywania na powietrzu, spacerze czy w ogrodzie. Specyficzną grupą są dzieci i ich rodzice - osoby te cierpią całymi rodzinami. Ich odczucia zmieniają się zależnie od etapu diagnostyki i leczenia [7]. Aspekt psychologiczny związany z obniżeniem jakości życia musi być wzięty pod uwagę podczas kwalifikacji do terapii.

\section{Patomechanizm reakcji}

Mówiąc o reakcji uogólnionej na jad owadów błonkoskrzydłych, mamy do czynienia z reakcją alergiczną IgE-zależną. Około $10 \%$ z nich ma charakter reakcji typu III czy IV według Coombsa czy charakter toksyczny [5]. Zazwyczaj pierwsze użądlenie nie wiąże się z wystąpieniem gwałtownej reakcji organizmu, a jedynie z aktywacją wielu procesów immunologicznych prowadzących do rozwoju alergii IgE-zależnej. Biorą w nich udział m.in. limfocyty Th2, komórki prezentujące antygen, limfocyty B, które docelowo produkują immunoglobuliny $\operatorname{IgE}$, a także interleukiny IL-4 i IL-13. Tak uczulone limfocyty B w kontakcie z alergenami jadu owadów będą produkować swoiste IgE, które z kolei aktywują komórki efektorowe, jakimi są bazofile i mastocyty. $\mathrm{Na}$ ich powierzchni są obecne receptory, które silnie wiążą się z fragmentami Fc immunoglobulin. W efekcie tego procesu dochodzi do degranulacji ziarnistości z komórek tucznych oraz uwolnienia mediatorów stanu zapalnego: histaminy i proteaz (m.in. tryptazy), katepsyny G, karboksypeptydazy, prostaglandyny $\mathrm{D}_{2}$, leukotrienów, czynnika aktywującego płytki i interleukin IL-4, IL-5, IL-13 oraz czynnika martwicy nowotworów (TNF-A, tumor necrosis factor) [5]. Głównym mediatorem odpowiedzialnym za objawy anafilaksji jest histamina, a wczesnym markerem tej reakcji jest podwyższone stężenie tryptazy w surowicy krwi.

Jad owadów błonkoskrzydłych składa się w ok. $30 \%$ z wody, resztę stanowią alergeny oraz substancje toksyczne. Jady poszczególnych owadów znacząco różnią się od siebie.

Najważniejsze alergeny jadu pszczoły i osy, mające znaczenie w toku diagnostyki, zostały wymienione w tabelach 1 i $2[3,6]$. Dla pszczoły są to fosfolipaza A2 (Api m 1, ok. 72\% uczulonych ma swoiste IgE, hialuronidaza (Api m 2), kwaśna fosfataza (Api $m$ 3), melityna (Api $m$ 4, główny składnik jadu pszczoły), alergen C (Api $m$ 5), inhibitor proteazy (Api $m$ 6, peptyd jest rozpoznawany przez przeciwciała IgE u 42\% osób uczulonych na jad pszczoły), ikarapina (Api $m$ 10, którego właściwości są ciągle w sferze badań, a który odgrywa znaczącą rolę w diagnostyce i leczeniu; szacuje się, że ok. 35-72\% uczulonych ma swoiste $\operatorname{IgE}$, a ich obecność stanowi istotny element diagnostyki w sytuacjach, gdy pacjent jest podwójnie uczulony; przypisuje się mu znaczenie w braku skuteczności immunoterapii swoistej (VIT, venom immunotherapy) [5]. W skład jadu osy wchodzą m.in.: fosfolipaza $\mathrm{A}_{1}$ (Ves $v 1$ - główny alergen jadu osy), hialuronidaza (Ves v 2 - sIgE są obecne u 10-12\% uczulonych na jad osy), dipeptydylopeptydaza (Ves $v 3$ - ma zdolność reagowania krzyżowego z Api $m$ 5), antygen $\mathrm{V}$ (Ves $v 5$ - jest głównym alergenem dla osowatych, występuje w jadzie większości gatunków os, szerszenia [Vesp c 5], klecanki, osy leśnej), witellogenina (Ves $v 6$, w dużej mierze odpowiedzialna za reakcje podwójnie dodatnie z jadem osy i pszczoły) [5].

\section{Diagnostyka}

Podstawę diagnostyki alergii na jad owadów błonkoskrzydłych stanowi dokładne zebranie wywiadu, w którym kluczowe jest zidentyfikowanie owada żądlącego. Istotne są informacje dotyczące okoliczności, w których doszło do użądlenia, np. obecność pasieki w pobliżu, to czy owad pozostawił żądło, odleciał, czy padł martwy. Istotne są również: pora roku, pora dnia, liczba użądleń, poprzednia reakcja na użądlenie. Zidentyfikowanie owada znacznie ułatwia poprowadzenie dalszego postępowania. Kolejną istotną informacją są opisywane objawy pojawiające się kolejno po 
sobie, ich intensywność, czas utrzymywania się, zastosowana terapia.

Większość reakcji dotyczy skóry i są to reakcje miejscowe. Utrzymują się maksymalnie do 24-72 h. Innym odczynem pozostaje tzw. duży odczyn miejscowy (LLR, large local reaction), definiowany jako obrzęk miejscowy o średnicy powyżej $10 \mathrm{~cm}$ narastający w czasie $24 \mathrm{~h}$, utrzymujący się nawet do $7 \mathrm{dni}$. U dzieci może obejmować najbliżej zlokalizowany staw i ograniczyć jego ruchomość. Badania pokazują jednak, że u takich pacjentów ryzyko uogólnionej reakcji po kolejnym użądleniu jest niewielkie i wynosi 2-15\% [8]. Należy jednak takich chorych pouczyć, jak mają postępować w przypadku kolejnego epizodu żądlenia, zaopatrzyć ich w leki stosowane miejscowo, leki antyhistaminowe w postaci doustnej, ewentualnie podjąć decyzję o dalszej diagnostyce i leczeniu, szczególnie gdy zgłaszają wyraźny niepokój. Anafilaktyczna reakcja uogólniona po użądleniu (SSR, systemic sting reaction) przebiega $\mathrm{w}$ mniej lub bardziej gwałtowny sposób, może być stanem zagrożenia życia. Charakteryzuje się ona ostrym początkiem (minuty do kilku godzin) z jednoczesnym zajęciem skóry i/lub błon śluzowych (np. uogólniona pokrzywka, świąd bądź zaczerwienienie, obrzęk wargi/języka/języczka) oraz przynajmniej jednym $\mathrm{z}$ poniższych symptomów ze strony innych układów: oddechowego (np. duszność, świszczący oddech - skurcz oskrzeli, stridor, obniżony szczytowy przepływ wydechowy [PEF, peak expiratory flow], hipoksemia), krążenia (spadek ciśnienia tętniczego krwi i jej następstwa, w tym hipotonia, omdlenie, utrata przytomności), pokarmowego (silny skurczowy ból brzucha, nawracające wymioty). Zajęcie skóry nie jest warunkiem koniecznym przy rozpoznaniu anafilaktycznej reakcji systemowej. Wystarczy rozpoznanie ostrego początku, niedociśnienia lub skurczu oskrzeli bądź zajęcia krtani po ekspozycji na znany lub wysoce prawdopodobny alergen dla tego pacjenta (minuty do kilku godzin) [9]. W ocenie klinicznej ciężkości przebiegu reakcji najczęściej używana przez alergologów jest skala Mullera.

Klasyfikacja uogólnionych objawów w przebiegu alergii na jady owadów według skali Mullera:

- pierwszy stopień - występują: pokrzywka, niepokój, ogólne osłabienie oraz świąd skóry

- drugi stopień - pojawiają się chociaż jeden z wyżej wspomnianych objawów oraz uczucie ucisku w klatce piersiowej, nudności, wymioty, obrzęk naczynioruchowy, ból brzucha, biegunka, zawroty głowy (muszą pojawić się przynajmniej dwa symptomy)
- trzeci stopień - występują jakikolwiek z wyżej wyróżnionych objawów oraz przynajmniej dwa z następujących: zaburzenia mowy, świszczący oddech, duszności, osłabienie, chrypka

- czwarty stopień - występuje któryś z powyższych symptomów lub przynajmniej dwa z następujących: utrata przytomności, niskie ciśnienie tętnicze, zapaść, problemy z trzymaniem moczu oraz stolca, sinica.

Zazwyczaj osoba użądlona trafia w pierwszej kolejności do gabinetu lekarza POZ, internisty lub na SOR i już na tym etapie powinno dojść do wstępnej selekcji kandydatów do dalszej terapii i diagnostyki. Każdy chory, który doświadczył dużej reakcji systemowej z interwencją pogotowia, a w niektórych przypadkach miejscowej i/lub objawów z dużym lękiem, powinien trafić do alergologa w celu dalszej diagnostyki.

Złotym standardem diagnostyki alergii na jad owadów błonkoskrzydłych (HVA, hymenoptera venom allergy) jest wykonanie testów skórnych prick z jadem w stężeniu $100 \mu \mathrm{g} / \mathrm{ml}$ i testów śródskórnych (IDT, intradermal tests) z jadem w stężeniach 0,001-1 $\mu \mathrm{g} /$ ml. Czułość tych testów jest najwyższa i wynosi odpowiednio dla testu prick 64\%, a kombinacja obu osiąga wartość 94\% [10]. Warto podkreślić, że testy te należy wykonać nie wcześniej niż po upływie 2 tygodni od ostatniego żądlenia. Jednocześnie jest zalecane oznaczenie poziomu sIgE. Możemy to wykonać bezpośrednio po użądleniu, a przy ujemnym wyniku powtórzyć za 4-6 tygodni [9]. Dodatnie wyniki testów skórnych i/lub sIgE potwierdzają uczulenie, a nie chorobę, czyli alergię na żądlącego owada. Nie są wskazaniem do VIT. Czułość testów serologicznych dla rodzaju Vespula jest niższa - od $83 \%$ do $97 \%$ - niż testów dla jadu pszczelego - od 98\% do 100\% [4].

Swoiste IgE są często obecne w wysokim mianie zarówno u osób żądlonych bez symptomów, jak i u tych, które prezentują jedynie LLR. Nie są one dobrym narzędziem diagnostycznym do przewidzenia nasilenia kolejnych reakcji [8]. Za dodatni uznaje się wynik powyżej 0,35 kU/1 [10]. Ponadto istnieje grupa pacjentów, u których mimo charakterystycznego wywiadu i reakcji poziomy sIgE nie korelują z wynikami testów skórnych. U tych chorych należy oznaczyć również poziom całkowitego IgE i przy niskich wartościach za dodani uznać wyniki sIgE powyżej $0,1 \mathrm{kU} / 1[10]$.

U pacjentów, u których testy podstawowe wskazują na alergię na oba jady, są ujemne mimo jasnego wywiadu anafilaksji po użądleniu lub wątpliwe, należy 
wykonać testy dodatkowe: test hamowania IgE, test aktywacji bazofilów (BAT, basophil activation test) lub molekularną diagnostykę alergii [11].

Testy hamowania $\operatorname{IgE} \mathrm{z}$ ekstraktami całego jadu owadów błonkoskrzydłych mogą być stosowane w szczególnych przypadkach do wykrycia pierwotnego jadu uczulającego u chorych podwójnie dodatnich na jady bez alergenów markerowych. Jednak testy hamowania IgE są kosztowne, czasochłonne, a wyniki czasami trudne do interpretacji.

Diagnostyka molekularna (tzw. komponentowa), jest zarezerwowana dla pacjentów, u których wyniki podstawowych testów są ujemne, niejednoznaczne, oraz dla osób podwójnie uczulonych. Polega ona na oznaczeniu w surowicy poziomów sIgE skierowanych wobec konkretnych składników poszczególnych jadów owadów. Czułość tych testów jest nieco mniejsza niż testów skórnych i sIgE; wynosi odpowiednio: panel dla osy $92 \%$, a dla pszczoły $-72 \%$. Warto podkreślić, że ma ona jednak ograniczone zastosowanie, ponieważ nie wszystkie istotne alergeny są dostępne. Jednakże, jeżeli Ves $v 1$ i Ves $v 5$ są ujemne, alergia na jad osy jest mało prawdopodobna. Jeśli chodzi o panel alergenów jadu pszczelego, to jego czułość jest również niska i niemożliwe jest zdiagnozowanie lub wykluczenie alergii na jad pszczoły. Jednak pojedynczy dodatni wynik Api $m 5$ może wskazywać na reakcję krzyżową z jadem osy i wyklucza alergię na jad pszczoły [11].

Poniżej rodzaje i opis dostępnych testów komponentowych w Polsce.

W niektórych ośrodkach wykonuje się również BAT. Czułość i swoistość tego testu różnią się w zależności od rodzaju owada: dla jadu pszczoły wynoszą odpowiednio $91 \%$ i $93 \%$, natomiast dla jadu osy $85 \%$ i 83\%, przy aktywności bazofilów > 10\% [12].

Podczas diagnostyki HVA u każdego pacjenta z rozpoznaną SSR należy oznaczyć bazowy poziom tryptazy. W przypadku wartości utrzymujących się powyżej 11,4 ng/ml konieczna jest diagnostyka w kierunku zespołu aktywacji mastocytów (MCAS, mast cell activation syndrome). W przypadku pierwotnego klonalnego MCAS, który jest wynikiem proliferacji monoklonalnych mastocytów z mutacją C-KIT CD25+, często rozpoznajemy mastocytozę skórną (CM, cutaneus mastocytosis) lub układową (SM, systemic mastocytosis).

Zauważono, że istnieje istotny związek tej choroby z HVA, ponieważ częstość mastocytozy u pacjentów z HVA jest stosunkowo wysoka [13].

Chorzy, u których w wywiadzie wystąpiły ciężkie reakcje po użądleniu, zwłaszcza w przypadku epizodów niedociśnienia tętniczego bez zmian skórnych, ze zwiększonym wyjściowym stężeniem tryptazy w surowicy $>25 \mu \mathrm{g} / \mathrm{ml}$, są narażeni na wysokie ryzyko wystąpienia pierwotnego (klonalnego) MCAS.

Wysokie stężenia tryptazy obserwuje się również w innych stanach chorobowych: przewlekłych infekcjach, w tym pasożytniczych, schyłkowej niewydolności nerek i u pacjentów poddawanych hemodializie, w zespołach mielodysplastycznych, ostrej białaczce szpikowej, przewlekłej białaczce szpikowej [14].

\section{Leczenie}

Do leczenia są kwalifikowani chorzy z potwierdzoną reakcją IgE-zależną, którzy reagują ciężkimi i umiarkowanymi objawami ogólnymi, osoby z symptomami skórnymi, u których wyraźny jest aspekt psychologiczny obniżenia jakości życia i którzy zgłaszają niepokój, a także pacjenci z LLR, u których występuje duże narażenie zawodowe na powtarzającą się ekspozycję na użądlenia owadów, np. pszczelarze.

Podstawową metodą leczenia uczulenia na jad owadów błonkoskrzydłych jest VIT. Składa się ona z fazy wstępnej i podtrzymującej. W warunkach polskich faza wstępna wiąże się zazwyczaj z kilkudniową hospitalizacją, podczas której podaje się zwiększające się dawki wyciągu jadu owadów w odstępach zazwyczaj 30-60 min. Jest to schemat rush. Istnieją także schematy ultra-rush, w których przypadku dawkę podtrzymującą osiąga się w ciągu 1-2 dni. Oba schematy są bezpieczne i dobrze tolerowane przez chorych [15]. Inne schematy, w tym konwencjonalny lub cluster, zakładają iniekcje wzrastających dawek w odstępach tygodniowych, a czas osiągnięcia dawki podtrzymującej wynosi od 6 do nawet 12 tygodni w protokole konwencjonalnym. Są one zarezerwowane dla pacjentów odczulanych w trybie ambulatoryjnym. Faza podtrzymująca polega na podawaniu dawki $100 \mu \mathrm{g} / \mathrm{ml}$ jadu w odstępach 4-8-tygodniowych (maksymalnie wydłużanych do 12 tygodni), w zależności od czasu trwania terapii, tolerancji, a także preparatu użytego do VIT. W Polsce do wyboru mamy roztwory wodne naturalnego wyciągu jadu osy i pszczoły oraz naturalne wyciągi jadu osy i pszczoły wzbogacone o adiuwant $\mathrm{Al}(\mathrm{OH})_{3}$, tzw. depot [5]. Efekty niepożądane podczas VIT są obserwowane u $8-20 \%$ pacjentów. Aby zminimalizować ich ryzyko, zaleca się przyjmowanie leków antyhistaminowych ok. 1-2 h przed iniekcją.

Bezwzględnym przeciwwskazaniem do VIT jest AIDS. Innymi bezwzględnymi przeciwwskazaniami, ale o charakterze czasowym, są: niekontrolowana astma, aktywna faza chorób autoimmunologicznych, 
Tabela 1. Rodzaj i opis testów komponentowych dla jadu pszczoly dostępnych w Polsce.

\begin{tabular}{|c|c|c|c|c|c|c|c|c|c|c|}
\hline Alergen & Molekuła & Nazwa & $\begin{array}{c}\text { Masa cząstecz- } \\
\text { kowa [kDa] }\end{array}$ & $\begin{array}{l}\% \text { suchej } \\
\text { masy jadu }\end{array}$ & Immuno & Alex2 & Faber & Isaac & Polycheck & $\begin{array}{l}\text { Panel Euro- } \\
\text { immun }\end{array}$ \\
\hline Ekstrakt & Api $m$ & jad pszczoły & & & $\checkmark$ & $\checkmark$ & $\checkmark$ & & $\checkmark$ & $\checkmark$ \\
\hline Molekuła & Api $m 1$ & fosfolipaza A2 & 16 & $10-12 \%$ & $\checkmark$ & $\checkmark$ & $\checkmark$ & $\checkmark$ & & $\checkmark$ \\
\hline Molekuła & Api $m 2$ & hialuronidaza & 39 & $1-2 \%$ & $\checkmark$ & & & & & $\checkmark$ \\
\hline Molekuła & Api $m 3$ & kwaśna fosfataza & 43 & $1-2 \%$ & $\checkmark$ & & & 2 & 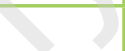 & \\
\hline Molekuła & Api $m 4$ & melityna & 2.8 & $40-60 \%$ & & & $\checkmark$ & $\checkmark$ & 8 & \\
\hline Molekuła & Api $m 5$ & dipeptydylopeptydaza IV & 102 & & $\checkmark$ & & t & 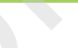 & & \\
\hline Molekuła & Api $m 6$ & $\begin{array}{l}\text { inhibitor trypsyny bogaty } \\
\text { w cysteinę }\end{array}$ & 8 & $1-2 \%$ & & & & & & \\
\hline Molekuła & Api 7 & proteaza serynowa CUB & 39 & $<1 \%$ & & 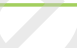 & & & & \\
\hline Molekuła & Api $m 8$ & karboksyloesteraza & 70 & $<1 \%$ & & & & & & \\
\hline Molekuła & Api $m 9$ & karboksypeptydaza serynowa & 60 & $<1 \%$ & & & & & & \\
\hline Molekuła & Api $m 10$ & ikarapina & $50-55$ & $?$ & $\checkmark$ & $\checkmark$ & & & & $\checkmark$ \\
\hline Molekuła & Api $m 11$ & $\begin{array}{l}\text { główne białko mleczka pszcze- } \\
\text { lego (major royal jelly protein) }\end{array}$ & 50 & $?$ & & & & & & \\
\hline Molekuła & Api $m 12$ & witellogenina & 200 & $?$ & & & & & & \\
\hline
\end{tabular}

Tabela 2. Rodzaj i opis testów komponentowych dla jadu osy dostępnych w Polsce.

\begin{tabular}{|c|c|c|c|c|c|c|c|c|}
\hline Alergen & Molekuła & Nazwa & CAP & Alex2 & Faber & Isaac & Poly check & Panel Euroimmun \\
\hline E & Ves v & jad osy pospolitej & $\checkmark$ & $\checkmark$ & $\checkmark$ & & $\checkmark$ & $\checkmark$ \\
\hline M & Ves $v 1$ & fosfolipaza A1 & $\checkmark$ & $\checkmark$ & & & & $\checkmark$ \\
\hline M & Ves $v 5$ & antygen 5 & $\checkmark$ & $\checkmark$ & & $\checkmark$ & $\checkmark$ & $\checkmark$ \\
\hline
\end{tabular}

Rycina 2. Schemat diagnostyki alergii na jad owadów błonkoskrzydlych (zmodyfikowano na podstawie [11]).

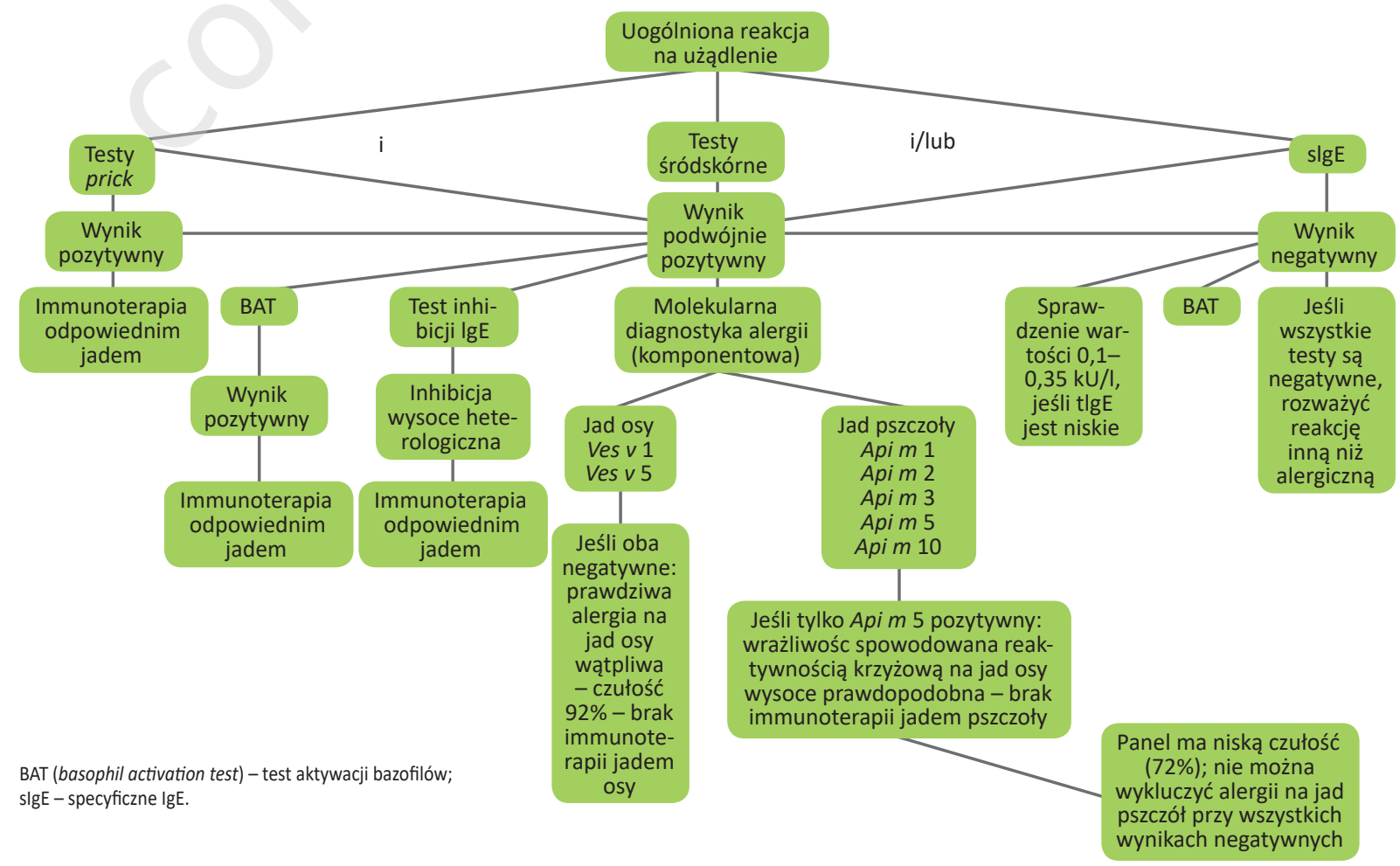


Rycina 3. Schemat kwalifikacji pacjentów do odczulania jadem owadów (zmodyfikowano na podstawie [11]).

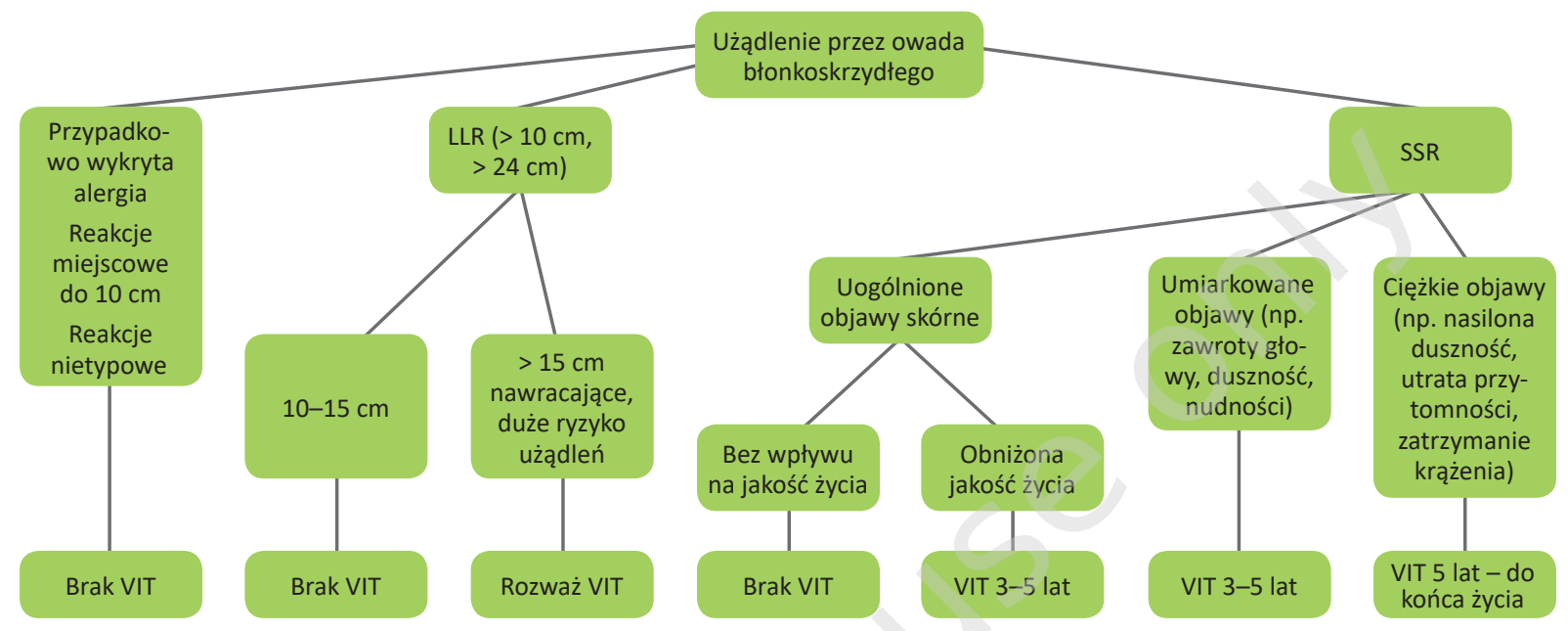

LLR (large local reaction) - duży odczyn miejscowy; SSR (systemic sting reaction) - reakcja uogólniona po użądleniu; VIT (venom immunotherapy) - immunoterapia swoista.

nowotwór złośliwy w trakcie leczenia (chemio- i radioterapia), ciąża (faza wstępna immunoterapii jadem owadów), wiek dziecka przed 2. r.ż. [16, 17].

\section{Skuteczność leczenia}

Terapia VIT jest najskuteczniejszą w alergologii i jej skuteczność wynosi 91-96\% przy alergii na jad osy oraz $77-84 \%$ przy alergii na jad pszczoły [16]. Obecnie uważa się, że już faza wstępna odczulania zabezpiecza chorego przed ciężkim przebiegiem reakcji w czasie kolejnego użądlenia [16]. Czas leczenia wynosi zazwyczaj od 3 do 5 lat. U niektórych pacjentów, głównie tych z mastocytozą i/lub ciężkim przebiegiem anafilaksji, a także ze zwiększonym narażeniem zawodowym, postuluje się, aby VIT utrzymać do końca życia.

Najskuteczniejszym narzędziem oceny skuteczności leczenia jest żądlenie polne, czyli przypadkowe użądlenie w trakcie leczenia. Żadne badanie diagnostyczne nie jest w stanie odpowiedzieć na pytanie, czy terapia była w pełni skuteczna - ani poziom sIgE, ani wyniki testów skórnych nie korelują z odpowiedzią na żądlenie po zaprzestaniu leczenia. Testem, który w przyszłości może pomóc w ocenie skuteczności VIT, jest BAT. Zaobserwowano bowiem, że zmiana wrażliwości bazofilów w ciągu pierwszych 3 tygodni immunoterapii alergenowej silnie korelowała z klinicznym efektem terapii w 1 . roku oraz po 3 latach leczenia. W związku z tym BAT mógłby się okazać cennym biomarkerem skuteczności immunoterapii oraz pomóc w podjęciu decyzji o zakończeniu leczenia [12]. Pacjenci z rozpoznaną LLR i SSR powinni do końca życia, w okresie zwiększonej aktywności owadów, nosić ze sobą leki zestawu ratunkowego, czyli lek przeciwhistaminowy, glikokortykosteroid w formie tabletek oraz ampułkostrzykawkę z adrenaliną.
W czasie pandemii COVID-19 wyraźnie spadła liczba chorych włączanych do VIT. Analiza ta została przeprowadzona w dużych ośrodkach zajmujących się HVA w Austrii, Niemczech i Szwajcarii. Porównano liczbę pacjentów włączonych do terapii wiosną 2019 i 2020 r. - liczba chorych spadła o 50\% [18]. Było to spowodowane głównie znacznym zmniejszeniem dostępności leczenia szpitalnego, a także strachem przed zakażeniem SARS-CoV-2 podczas wizyty w ośrodku medycznym. Doświadczenie to pokazuje, że w czasie pandemii należy kontynuować VIT w warunkach ambulatoryjnych.

W ww. krajach powstały nawet specjalne zalecenia, mające na celu zapewnienie ciągłości opieki nad chorymi z HVA w trakcie pandemii [18]:

- zwiększenie dostępności wizyt w formie teleporad i wideoporad

- zmiana aranżacji poczekalni i wdrożenie środków higienicznych i socjalnych

- wprowadzenie zasad dystansowania

- współpraca z lekarzami POZ w zakresie diagnostyki podstawowej HVA (oznaczenie sIgE dla jadów osy i pszczoły)

- szybkie testy na COVID-19 przed kursami wstępnymi immunoterapii w ramach hospitalizacji

- kontynuacja VIT w trybie ambulatoryjnym, z zachowaniem odstępów kolejnych iniekcji

- rozpoczęcie immunoterapii jadem owadów w sezonie aktywności owadów schematami rush i ultra-rush; a jeśli to konieczne - korzystanie z protokołów ambulatoryjnych, zwłaszcza poza sezonem aktywności owadów

- wyraźne odniesienie się do sytuacji związanej z COVID-19 w trakcie konsultacji lekarskich 
- w przypadku ograniczenia pracy ośrodka triage pacjentów w zależności od ciężkości przebiegu reakcji

- dostosowanie organizacji oddziału, np. współpraca z innymi oddziałami

- wydłużony czas pracy przychodni, pobyty weekendowe, aby zapewnić opiekę chorym z HVA

- oznaczanie sIgE.

\section{Podsumowanie}

Uczulenie na jad owadów błonkoskrzydłych stanowi istotny problem medyczny dla sporej grupy pacjentów. Ogranicza ono ich normalne funkcjonowanie, często obniża jakość życia i nierzadko stanowi jego zagrożenie. Jedyną skuteczną metodą leczenia alergii na jad owadów jest VIT, który chorym pozwala w dużej mierze zapomnieć o ich obawach związanych z użądleniami i jednocześnie znacznie poprawia komfort życia.

\section{Warto zapamiętać}

Testy skórne:

- są złotym standardem w diagnostyce HVA

- w celu uniknięcia wyników fałszywie ujemnych należy wykonywać je po upływie co najmniej 2 tygodni od ostatniego użądlenia, a jeśli wynik jest ujemny - powtórzyć po 1-2 miesiącach

- są bezpieczne dla pacjentów z mastocytozą i podwyższonym stężeniem tryptazy

- testy punktowe muszą być zintegrowane z testami śródskórnymi, nawet jeśli są pozytywne

- testy śródskórne: preferowane jest jednoczesne testowanie tego samego stężenia większej liczby jadów, ze zwiększającymi się stężeniami tylko wtedy, gdy poprzednie było ujemne.

sIgE :

- istotne z punktu widzenia diagnostyki jest używanie tylko zwalidowanych testów

- łącznie z testami skórnymi są one wystarczającym narzędziem do kwalifikacji do VIT.

Testy molekularne (komponentowe):

- stosowane w przypadku podwójnego uczulenia lub w przypadku ujemnych wyników testów, z sugestywnym wywiadem reakcji ogólnoustrojowej.

Test hamowania IgE:

- przydatny do rozróżniania wielu uczuleń, jeśli wyniki testów komponentowych są niejednoznaczne.
BAT:

- wysoce specyficzna technika diagnostyczna wykonywana w wybranych laboratoriach

- test stosowany $\mathrm{u}$ pacjentów $\mathrm{z}$ zaburzeniami komórek tucznych i ujemnym sIgE.

Tryptaza:

- należy zawsze ocenić poziom bazowy w przypadku reakcji ogólnoustrojowej, zwłaszcza z towarzyszącą hipotensją

- wysoki poziom wyjściowy w powtarzanych pomiarach sugeruje zaburzenia komórek tucznych, które należy poddać dalszej diagnostyce.

\section{Piśmiennictwo}

1. Jahnz-Różyk K, Jutel M, Kucharczyk A et al. Rekomendacje Zespołu Ekspertów pod kierunkiem Konsultanta Krajowego $w$ dziedzinie Alergologii dotyczace szczepienia przeciwko COVID-19 szczepionka mRNA (Comirnaty) dla Lekarzy kwalifikujących do szczepienia i dla Konsultantów Alergologów. Med Prakt. 2020: 1: 58-62.

2. Kruszewski J, Cichocka-Jarosz E, Czarnobilska E et al. Recommendations of the Polish Society of Allergology on the qualification of person with allergies and anaphylaxis to vaccination against COVID-19. Alergol Pol - Polish J Allergol. 2021; 8(1): 1-8.

3. Antonicelli L, Bilò MB, Bonifazi F. Epidemiology of Hymenoptera allergy. Curr Opin Allergy Clin Immunol. 2002; 2(4): 341-6.

4. Bilò MB, Pravettoni V, Bignardi D et al. Hymenoptera venom allergy: Management of children and adults in clinical practice. J Investig Allergol Clin Immunol. 2019; 29: 180-205.

5. Nittner-Marszalska M. Alergia na owady. Alergologia w Praktyce. Mediton, Łódź 2016.

6. Müller UR. Bee venom allergy in beekeepers and their family members. Curr Opin Allergy Clin Immunol. 2005; 5: 343-7.

7. Cichocka-Jarosz E, Brzyski P, Tarczoń I et al. Quality of life in parents of children and adolescents after systemic sting reactions. Ann Agric Environ Med. 2019; 26: 315-21.

8. Tripolt P, Arzt-Gradwohl L, Čerpes U et al. Large local reactions and systemic reactions to insect stings: Similarities and differences. PLoS One. 2020; 15: 1-8.

9. Cardona V, Ansotegui IJ, Ebisawa M et al. World allergy organization anaphylaxis guidance 2020. World Allergy Organ J. 2020; 13: 100472.

10. Blank S, Grosch J, Ollert M et al. Precision Medicine in Hymenoptera Venom Allergy: Diagnostics, Biomarkers, and Therapy of Different Endotypes and Phenotypes. Front Immunol. 2020; 11: 1-17. 
11. Sturm GJ, Arzt-Gradwohl L, Varga EM. Medical Algorithms: Diagnosis and treatment of Hymenoptera venom allergy. Allergy Eur J Allergy Clin Immunol. 2019; 74: 2016-18.

12. Santos AF, Alpan O, Hoffmann HJ. Basophil activation test: Mechanisms and considerations for use in clinical trials and clinical practice. Allergy Eur J Allergy Clin Immunol. 2021; 76: 2420-32.

13. Zanotti R, Lombardo C, Passalacqua G et al. Clonal mast cell disorders in patients with severe Hymenoptera venom allergy and normal serum tryptase levels. J Allergy Clin Immunol. 2015; 136: 135-9.

14. Valent P, Bonadonna P, Hartmann K et al. Why the $20 \%+2$ Tryptase Formula Is a Diagnostic Gold Standard for Severe Systemic Mast Cell Activation and Mast Cell Activation Syndrome. Int Arch Allergy Immunol. 2019; 180: 44-51.

15. Stock R, Fischer T, Aßmus $K$ et al. Safety and tolerability of venom immunotherapy: Evaluation of 581 rush- and ultra-rush induction protocols (safety of rush and ultra-rush venom immunotherapy). World Allergy Organ J. 2021; 14(1):100496.

16. Sturm GJ, Varga EM, Roberts $G$ et al. EAACI guidelines on allergen immunotherapy: Hymenoptera venom allergy. Allergy Eur J Allergy Clin Immunol. 2018; 73: 744-64.

17. Nittner-Marszalska M. Immunoterapia $w$ alergii na jad owadów błonkoskrzydłych. Alergol Pol - Polish J Alergol. 2018: 85-93.
18. Worm M, Ballmer-Weber B, Brehler R et al. Healthcare provision for insect venom allergy patients during the COVID-19 pandemic. Allergo J Int. 2020; 29: 257-61.

ORCID

E. Czarnobilska - ID - http://orcid.org/0000-0002-5410-6084

Wkład autorów/Authors' contributions:

W. Sułkowska: 50\%; E. Czarnobilska: 50\%

Konflikt interesów/Conflict of interests:

Nie występuje.

Finansowanie/Financial support:

Nie wystęuju.

Etyka/Ethics:

Treści przedstawione w artykule są zgodne z zasadami Deklaracji Helsińskiej, dyrekktywami EU oraz ujednoliconymi wymaganiami dla czasopism biomedycznych.

Copyright: @ Medical Education sp. Z 0.0. This is an Open Access article distributed under the terms of the Attribution-NonCommercial 4.0 International (CC BY-NC 4.0). License (https://creativecommons.org/licenses/by-nc/4.0/), allowing third parties to copy and redistribute the material in any medium or format and to remix, transform, and build upon the material, provided the original work is properly cited and states its license.

Adres do korespondencji

prof. dr hab. n. med. Ewa Czarnobilska

Zakład Alergologii Klinicznej i Środowiskowej, Katedra Toksykologii i Chorób Środowiskowych, Wydział Lekarski, Uniwersytet Jagielloński Collegium Medicum 31-503 Kraków, ul. Botaniczna 3 tel.: 124248630,124248650 e-mail: ewa.czarnobilska@uj.edu.pl 